\title{
NOWA DYPLOMACJA PUBLICZNA - PERSPEKTYWA TEORII STOSUNKÓW MIĘDZYNARODOWYCH I KOMUNIKOWANIA POLITYCZNEGO
}

Pojęcie „,nowej dyplomacji publicznej” zostało wprowadzone dla odróżnienia jej od „starej” - jednostronnej, asymetrycznej komunikacji politycznej Stanów Zjednoczonych, prowadzonej do 1999 r. pod kierownictwem United States Information Agency (USIA). Po 2001 r. ukazało się wiele publikacji zawierających w tytule to sformułowanie $^{1}$, co ugruntowało jego użycie, zwłaszcza w badaniach nad dyplomacją. Cezurami dla wielkich zmian w tej dziedzinie - zarówno w teorii jak i praktyce - były lata 1989 oraz 2001. O ile rok 1989 symbolizuje koniec zimnej wojny, co oznacza także koniec historii tradycyjnej dyplomacji publicznej USA, to po 2001 r., na skutek ataków na World Trade Center, odżyła dyskusja nad rolą mediów i zastosowaniem miękkiej siły w stosunkach międzynarodowych.

Kwestię „,nowej dyplomacji publicznej” wybrano dla rozważań nad interdyscyplinarnością w badaniach nad stosunkami międzynarodowymi ze względu na fakt, iż zjawisko to można analizować jedynie przy zastosowaniu narzędzi pochodzących zarówno z teorii stosunków międzynarodowych, jak i komunikowania politycznego. Należy przy tym dodać, że celowo upraszczam problem, wymieniając tylko te dwie dziedziny. Rozważania nad dyplomacją publiczną wywodzą się bowiem także z badań nad dyplomacją (o ile wydzielimy ją ze stosunków międzynarodowych), medioznawstwa, public relations oraz szerzej z historii i kulturoznawstwa. Interdyscyplinarność w tym przypadku wymaga dyscypliny badawczej, aby uniknąć metodologicznego chaosu. Oznacza przy tym raczej sumę metod badawczych pochodzących z wielu dyscyplin, niż nową jakość w postaci nowego podejścia badawczego.

Podejście umiejscawiające dyplomację publiczną w nauce o stosunkach międzynarodowych, a zwłaszcza w badaniach nad dyplomacja, jest dominujące ${ }^{2}$, reprezentująje m.in. E. Gilboa i J. Melissen. E. Gilboa postrzega dyplomację publiczną jako jeden ze sposobów, w jaki środki masowego przekazu są wykorzystywane jako instrument poli-

1 J. Melissen, Wielding Soft Power: The New Public Diplomacy, Clingendael Diplomacy Papers, May 2005; The New Public Diplomacy. Soft Power in International Relations, ed. J. Melissen, Palgrave McMillan, London 2007; E. Potter, Canada and the New Public Diplomacy, „Discussion Papers in Diplomacy" 2002, No. 81.

2 Przekonać się można o tym, porównując jak często tematyka ta pojawia się na dorocznych kongresach dwóch głównych organizacji międzynarodowych z dziedziny stosunków międzynarodowych - ISA i komunikowania - ICA. Obie organizacje mają sekcje komunikowania międzynarodowego, zdecydowanie częściej problem ten jest jednak dyskutowany na obradach ISA. 
tyki zagranicznej i negocjacji międzynarodowych ${ }^{3}$. Główną ideą takiej działalności jest wpłynięcie na rząd za granicą przez oddziaływanie na jego obywateli. J. Melissen przyjmuje z kolei, że uznanie dyplomacji publicznej za jedno z narzędzi polityki zagranicznej byłoby uproszczeniem. Nadaje mu szersze znaczenie, uznając dyplomację publiczną za część „fabryki, gdzie produkuje się politykę światową”4 .

Pojawienie się przymiotnika „nowa” oznacza dostosowanie się dyplomacji do zmian zachodzących w środowisku międzynarodowym na skutek globalizacji. „Nowa” oznacza chronologicznie dyplomację publiczną uprawianą w okresie postzimnowojennym. Definiuję ją jako dialogową formę międzynarodowego komunikowania politycznego, które przez budowanie wzajemnie korzystnych relacji z partnerami za granica, ułatwia realizację celów państwa w środowisku międzynarodowym. Definicja ta po pierwsze odwołuje się do rozumienia dyplomacji jako procesu komunikacji; po drugie wywodzi się z definicji public relations (które zwykle zawierają w sobie ideę budowania wzajemnie korzystnych relacji z otoczeniem, tzw. interesariuszami), po trzecie zaś kładzie silny akcent na państwo, jako na głównego aktora dyplomacji publicznej lub w ujęciu analizy sieciowej w politologii na węzeł w sieci, jakąjest nowa dyplomacja publiczna. Rola państwa wyjaśnia, dlaczego definicja zawiera w sobie pojęcie „międzynarodowości”, które w pierwszym rzędzie odnosi się do relacji między państwami. Badania nad dyplomacją publiczną odwołują się do kluczowych kategorii nauki o stosunkach międzynarodowych - siły i władzy. Zgodnie z powyższym, badania nad nową dyplomacją publiczna, opierają się zarówno na takich narzędziach jak analiza polityki zagranicznej, jak i analiza relacji między mediami a polityka, a zwłaszcza nad procesami opiniotwórczymi.

Dyplomację publiczną uznaję współcześnie za jedno z narzędzi miękkiej siły. Celowo wprowadzam w tym miejscu to pojęcie, wywodzące się z artykułów i książek J. S. Nye'a, gdyż w wielu studiach nad dyplomacją publiczną jest ono ramą dla analizy, a jednocześnie doskonałą ilustracją problemów metodologicznych współczesnej nauki o stosunkach międzynarodowych. J. Nye nazywa miękką siłę siłą do, a nie (władzą) nad czymś. W swej ostatniej publikacji The Future of Power (2010) autor ten, próbując podsumować wielki renesans tego pojęcia, wywołany wcześniejszą publikacją Soft Power. The Means to Success in World Politics (Public Affairs, 2004), włączył do swoich rozważań elementy teorii komunikacji politycznej oraz psychologii komunikowania. Nie powstała przy tym jednak żadna nowa wartość w nauce o stosunkach międzynarodowych. J. Nye wprowadzając koncepcję miękkiej i sprytnej siły odpowiada na deficyty neorealistycznej analizy stosunków międzynarodowych, przede wszystkim na problem wieloaktorowości tych stosunków. Zgodnie z wczesnymi definicjami J. Nye’a miękka siła była definiowana w opozycji do „siły twardej” - militarnej i gospodarczej. Oznaczała ona wykorzystanie potencjału ideologicznego i kulturowego danego państwa, na którym buduje się jego wiarygodność i atrakcyjność ${ }^{5}$. Wiarygodność jest kluczowym

3 E. Gilboa, Diplomacy in the Media Age. Three Models of Uses and Effects, „Diplomacy \& Statecraft" 2001, no 12 (2), s. 4 i n.

4 The New Public Diplomacy: Soft Power in International Relations, ed. J. Melissen, Palgrave Macmillan, London 2007, s. 6.

5 J. Nye, Soft Power. The Means to Success in World Politics, Public Affairs, New York 2004, wyd. polskie pod tytułem Soft Power. Jak osiagnać sukces w polityce światowej, Wydawnictwa Akademickie i Profesjonalne, Warszawa 2007. 
pojęciem dla rozważań nad miękką siłą i dyplomacją publiczną. Miękką siłę należy więc pojmować jako narzędzie polityki zagranicznej, służące pozycjonowaniu państw, oddziałujące w kombinacji z wszystkimi dostępnymi aktorom komunikowania międzynarodowego środkami. Połączenie środków „miękkich” i „twardych” określane jest przez J. Nye jako ,sprytna siła” (ang. smart power) ${ }^{6}$. Koncepcja „,sprytnej siły” jest rozwijana przez J. Nye we wspomnianej wyżej książce The Future of Power. J. Nye przyjmuje, że użycie miękkich środków, ich kombinacja w postaci „sprytnej siły”, efekty jakie dzięki nim można uzyskać zależą od kontekstu, w jakim odbywa się polityka zagraniczna. Wprowadza - jako jeden z zasobów siły - kategorię ustalania porządku dnia i uramowienia, stanowiące w tej chwili główne koncepcje komunikacji politycznej. Obie mogą występować jako narzędzia siły twardej i miękkiej. Stanowią one jeden z łączników między podejściem teorii stosunków międzynarodowych i teorii komunikowania politycznego.

Miękka siła stosowana jest $\mathrm{w}$ relacjach międzynarodowych od ich początków. Obecne zainteresowanie tematem wynika ze zmian w środowisku międzynarodowym, ale także z rosnącej w wieku wizualności fascynacji takimi dziedzinami jak marketing polityczny i międzynarodowe public relations, które zdają się oferować proste do zastosowania narzędzia, przynoszące szybko oczekiwane efekty w polityce, w tym w stosunkach międzynarodowych. Podejście „miękkiej siły” zakłada przy tym, że na zachowanie państwa w stosunkach międzynarodowych wpływają m.in. kultura polityczna, w tym kultura polityki zagranicznej. Wewnętrzny wymiar polityki zagranicznej jest istotny dla sposobu rozumienia i wykorzystania miękkiej siły, a często decyduje o tym, czy w ogóle metody „miękkie” będą wprowadzane do strategii polityki zagranicznej (a także do grand strategy). Wymiar wewnętrzny dyplomacji publicznej jako narzędzia miękkiej siły oznacza sposób komunikowania jej obywatelom i konsultowania jej z obywatelami, o ile takie konsultacje w ogóle brane są pod uwagę, a także stopień poparcia dla strategii dyplomacji publicznej. Wprowadzanie do nauki o stosunkach międzynarodowych kategorii miękkiej lub sprytnej siły i dyplomacji publicznej nieuchronnie prowadzi do dyskusji nad kategorią siły w stosunkach międzynarodowych i nad różnicą między dyplomacją publiczną i propagandą. Pierwszy problem tkwi swoimi korzeniami w teorii stosunków międzynarodowych, drugi w teorii komunikowania politycznego.

Na specyfikę współczesnej dyplomacji publicznej, jako jednego z narzędzi polityki zagranicznej, a więc od strony praktycznej oraz jako na problem teorii stosunków międzynarodowych i komunikowania politycznego wskażę nawiązując do koncepcji aren komunikowania politycznego J. Habermasa. Wracając do swoich rozważań wyjaśniających między innymi jak kształtuje się opinia publiczna w 2006 r., J. Habermas uwzględnił znaczenie mediów w przekształcaniu opinii opublikowanych i opinii publiczności w opinię publiczną. Stosując koncepcję trzech aren, na których odbywa się komunikacja polityczna według J. Habermasa do dyplomacji publicznej otrzymujemy następujące trzy poziomy dyplomacji publicznej (tabela 1).

${ }^{6}$ Ibidem, wydanie polskie, s. 28. 
Trzy poziomy dyplomacji publicznej

\begin{tabular}{|l|l|l|l||}
\hline $\begin{array}{l}\text { Poziom centrum systemu politycz- } \\
\text { nego: rządy, parlamenty, sądy }\end{array}$ & $\begin{array}{l}\text { Strategie polityki zagranicznej, grand strategy, } \\
\text { strategie dyplomacji publicznej }\end{array}$ & agenda polityków \\
\hline $\begin{array}{l}\text { Peryferie systemu politycznego: } \\
\text { system medialny }\end{array}$ & Media, organizacje pozarządowe, lobbyści & $\mathrm{g} 2 \mathrm{p}$ & agenda mediów \\
\hline $\begin{array}{l}\text { Codzienna komunikacja publicz- } \\
\text { na: społeczeństwo obywatelskie }\end{array}$ & $\begin{array}{l}\text { Obywatele, ruchy społeczne, sieci (w tym media } \\
\text { społecznościowe), dyplomacja obywatelska }\end{array}$ & $\mathrm{p} 2 \mathrm{p}$ & $\begin{array}{l}\text { agenda publiczności } \\
\text { (interesariuszy) }\end{array}$ \\
\hline
\end{tabular}

Źródło: Na podstawie: J. Habermas, Political Communication in Media Society - Does Democracy still Enjoy an Epistemic Dimension? The Impact of Normative Theory on Empirical Research, referat wygłoszony podczas ICA Annual Convention 2006, Drezno, 20.06.2006.

Powyższy schemat odwołuje się do funkcjonowania sfery publicznej, w której powstaje opinia publiczna. Włączenie aktorów niepaństwowych wskazuje, że współczesna dyplomacja publiczna kształtuje się na wszystkich poziomach, a nie jak klasyczna dyplomacja w centrum systemu politycznego oraz że jest to proces dwustronny: odbywa się w układzie wertykalnym w obu kierunkach, w obrębie społeczeństwa danego państwa, m.in. wówczas, gdy dochodzi do debaty publicznej na temat polityki zagranicznej. Jest to wzmiankowany wyżej wewnętrzny wymiar dyplomacji publicznej, w którym pojawiają się m.in. badania nad włączeniem organizacji pozarządowych do kształtowania polityki zagranicznej oraz nad znaczeniem kształtowania marki kraju dla jego tożsamości kulturowej. Dwustronność dotyczy także wymiaru horyzontalnego. W relacjach tych budowana jest wiarygodność partnerów. Dawny odbiorca jednostronnych przekazów, wysyłanych za granicę, staje się partnerem wzajemnych relacji, w których obie strony dzięki zaangażowaniu podlegają przemianom, a zachodzące procesy kulturowe przybierają formę hybrydyzacji ${ }^{7}$. Koncepcja hybrydyzacji, wywodząca się z komunikowania międzykulturowego i kulturoznawstwa, jest potencjalnie jednym z podejść analitycznych w badaniach nad dyplomacją publiczną. Ilustruje ona kulturową logikę procesów globalizacji, stanowiąc kontrpropozycję dla kulturowego pluralizmu i kulturowego imperializmu ${ }^{8}$. Podkreśla ona symetryczność, gdyż w tym ujęciu międzykulturowe relacje prowadzą do zmian u obu partnerów. Hybrydyzacja wskazuje m.in. na błędy w utożsamianiu nowej dyplomacji publicznej z kulturowym imperializmem. W niektórych podejściach bowiem dyplomacja publiczna jest traktowana jako eufemizm dla imperializmu kulturowego. Tymczasem, jak podkreślał P. Taylor, staje się ona najważniejszym paradygmatem komunikowania międzynarodowego, następując po imperializmie kulturowym ${ }^{9}$.

Na poziomie centrum systemu politycznego utrzymuje się oddziaływanie metodami klasycznej dyplomacji, oznaczone jako g2g: rząd do rządu (ang. government to government). Na poziomie peryferii systemu politycznego włączane są media jako po-

7 Jak w koncepcji M. Kraidy, Hybridity or the Cultural Logic of Globalisation, Temple University Press, Philadelphia 2005.

8 Ibidem, s. 150.

9 P. M. Taylor, Public diplomacy and Strategic Communication, w: Handbook of Public Diplomacy, eds. N. Snow, P. M. Taylor, Routledge, London 2008, s. 17. 
średnicy, ale także jako aktorzy dyplomacji publicznej (niepaństwowi aktorzy dyplomacji publicznej). Na tym poziomie relacje mogą nadal być inicjowane i całkowicie kontrolowane przez państwo, tylko koordynowane przez państwo lub przezeń obserwowane. Na poziomie trzecim, w systemach otwartych, państwu pozostaje rola koordynatora i obserwatora. To rozróżnienie wskazuje po raz kolejny na potrzebę włączenia do rozważań nad dyplomacją publiczną klasycznego dla nauki o stosunkach międzynarodowych problemu siły, władzy i suwerenności.

Dla ustalenia strategii dyplomacji publicznej na poziomie pierwszym istotne jest wprowadzenie elementów analizy polityki zagranicznej. Swoją ważność zachowuje podejście geopolityczne, analiza położenia geopolitycznego kraju i ustalenie znaczenia geopolityki w tworzeniu podstaw polityki zagranicznej państwa. Geopolityka, zasoby twarde państwa będą wpływać na znaczenie informacyjne kraju, a w tym na jego międzynarodowe postrzeganie, począwszy od postrzegania kraju w kategoriach zasobów twardych lub miękkiej siły. Zasoby miękkie są szczególnie istotne dla państw małych i średnich. Także w przypadku mocarstw jednak ich zaniedbanie prowadzi do istotnych szkód wizerunkowych (jak w przypadku USA po interwencji w Iraku). Państwa o dużym potencjale zasobów twardych, mają tendencję do stosowania informacyjnej, jednostronnej dyplomacji publicznej. Koncepcja informacyjnej dyplomacji publicznej wywodzi się z typologii zaproponowanej przez R. Zaharnę ${ }^{10}$. Formy informacyjne dominują $\mathrm{w}$ systemach autorytarnych oraz $\mathrm{w}$ sytuacjach ograniczenia swobody przepływu informacji, jak konflikty zbrojne. Należy do nich także reklama i kształtowanie marki (ang. branding), ale także nadawanie za granicę (jak Gtos Ameryki i Radio Wolna Europa), zwłaszcza, gdy nie towarzyszą mu narzędzia ułatwiające interakcję lub gdy odbywa się w kierunku systemów zamkniętych.

Jedną z form informacyjnej (jednostronnej) komunikacji politycznej jest propaganda. Pojęcie propagandy nie budzi kontrowersji w nauce o stosunkach międzynarodowych. W nauce o komunikowaniu trwa zaś dyskusja, ożywiona poprzez koncepcje nowej dyplomacji publicznej, jakie czynniki pozwalają odróżnić te dwie formy komunikacji politycznej. Przy założeniu, że propaganda to jednostronna komunikacja, której celem jest zmiana zachowania odbiorców, z pominięciem budowania współzależności i uwzględniania interesów obu stron procesu komunikacji, to taką formę komunikacji można odnaleźć jako dominującą w systemach autorytarnych, w tych systemach politycznych, gdzie istnieją zamknięte, lub częściowo zamknięte systemy medialne, a także w konfliktach zbrojnych, gdy prowadzi się walkę informacyjną i ogranicza wolność słowa. Pojawienie się elementów manipulacyjnych w komunikacji politycznej oznacza, że ma ona cechy propagandy, niezależnie od typu systemu politycznego i medialnego. Uprawianie propagandy $\mathrm{w}$ systemach demokratycznych oraz w relacjach między państwami demokratycznymi jest utrudnione ze względu na swobodny dostęp obywateli do wielu źródeł informacji, a więc ze względu na możliwość weryfikacji przekazów.

W badaniach nad strategią dyplomacji publicznej na poziomie pierwszym stosowana jest analiza dokumentów rządowych $i$ analizy statystyczne. Tym samym należy pod-

10 R. S. Zaharna, The Soft Power Differential: Network Communication and Mass Communication in Public Diplomacy, „The Hague Journal of Diplomacy” 2007, no 2 (3), s. 213-222. 
kreślić, że koncepcja (nowej) dyplomacji publicznej nie pozostaje w sprzeczności z ujęciami neorealistycznymi. Ujęcie geopolityczne przyczynia się do rozpoznania modelu dyplomacji publicznej, wyjaśnia m.in. wybór państw docelowych i tematów kampanii, stanowi podstawę dla zrozumienia dużego znaczenia dyplomacji historycznej (inaczej: zagranicznej polityki historycznej) dla niektórych państw. Na tym poziomie w przygotowaniu strategii dyplomacji publicznej stosuje się analizę SWOT (ang. Strengths, Weaknesses, Opportunities, Threats). Na poziomie drugim odbywa się proces artykulacji opinii publicznej, w którym to media pełnią główną rolę, przekształcając opinie publiczności w opinie opublikowane i - zgodnie z koncepcją ustalania porządku dnia - wprowadzając tematy i zagadnienia do debaty publicznej, a poprzez mechanizm uramowienia, nadając im także interpretacje. Na tym poziomie istotne jest badanie postrzegania międzynarodowego i wizerunku państw, a także ich marki, rozumianej jako (pozytywne) wartości, kojarzone z danym państwem i społeczeństwem, przekładające się na (pozytywne) postawy wobec państwa. Mimo licznych krytyk warte zauważenia są dążenia do pomiaru marki państwa, jak Nation Brand Index (NBI) S. Anholta. Indeks ten jest tworzony na podstawie sześciokąta kanałów komunikacji, na który składają się czynniki ekonomiczne (w tym efekt kraju pochodzenia), polityka wewnętrzna i zagraniczna (m.in. przestrzeganie praw człowieka); inwestycje i imigracja; dziedzictwo kulturowe, ludzie oraz turystyka. Sześć dziedzin wskazuje, co wpływa na międzynarodowe postrzeganie kraju i co ma znaczenie dla uznania go za markę. Na podstawie sześciokąta powstaje lista pytań, które w formie ankiety przedstawiane są respondentom, reprezentującym wpływowe grupy społeczne, w dwudziestu krajach świata ${ }^{11}$. Ich odpowiedzi służą do pomiaru marki kraju: na tej podstawie powstaje NBI S. Anholta.

Na poziomie drugim $\mathrm{w}$ analizie dyplomacji publicznej istotna jest dekonstrukcja wizerunków i marek państw, prowadzona również przez kulturoznawców, w tym analiza zawartości mediów i badania sondażowe. Charakterystyczny jest przy tym nurt, łączący badania kulturoznawcze z podejściem public relations i opierający się na koncepcji pola P. Bourdieu. Nurt ten analizuje związki między tożsamością narodową społeczeństw Europy Środkowo-Wschodniej a kształtowaniem ich marki w środowisku międzynarodowym. Kształtowanie marki jest jednak przede wszystkim działalnością jednokierunkowa, w rozumieniu R. Zaharny - informacyjną. Według D. Copelanda „branding narodowy obejmuje opowiadanie unikatowej historii i jej wyrażenie jako zintegrowanej narracji o klarownym kształcie i celu"12. Tak sformułowana definicja nawiązuje do pojęcia dyplomacji publicznej C. Schneider, według której jest to narracja, którą naród opowiada światu o sobie ${ }^{13}$. W takim ujęciu duże znaczenie przypisuje się dyplomacji kulturalnej, a w jej ramach zagranicznej polityce historycznej.

We wcześniejszych analizach zwrócono uwagę na niechęć specjalistów od brandingu, wywodzących się z public relations do nadużywania koncepcji dyplomacji publicz-

11 W latach 2009-2011 „megamarką” według NBI S. Anholta były Stany Zjednoczone.

12 D. Copeland, The Seven Paradoxes of Public Diplomacy, w: Trials of Engagement. The Future of US Public Diplomacy, eds. A. Fischer, S. Lucas, Martinus Nijhoff Publishers, Leiden 2011, s. 186.

${ }_{13}$ C. Schneider, Culture Communicates: US Diplomacy that Works, „Discussion Papers in Diplomacy", Clingendael 2004, no 94, s. 1. 
nej. Ich rozumienie brandingu w ostatnim czasie zdecydowanie jednak ewoluuje. S. Anholt zwraca uwagę, że branding państw i branding narodów powinien się stać elementem polityki lub szerszej strategii komunikacji danego państwa. N. Kaneva analizuje zjawisko kształtowania matki kraju i narodu z punktu widzenia jej relacji do tożsamości narodowej, w ujęciu antropologicznym. Rozszerza pojęcie marki państwa zwracając uwagę, że jej funkcją jest ,zrekonstruować narodowość na poziomie zarówno ideologii, jak i praktyki, dzięki temu rozumienie i doświadczana realność przynależności narodowej i kształtowania tego co narodowe (ang. national governance) zmieniają się w sposób dotąd nieznany"14.

Rozpowszechnienie się metod wywodzących się z public relations $\mathrm{w}$ polityce zagranicznej jest skutkiem jej ekonomizacji. Przebieg tego procesu na przykładzie Niemiec przeanalizował R. Hülsse ${ }^{15}$. R. Hülsse używa określenia „wizerunkowa polityka zagraniczna”, które oznacza „wysiłki na rzecz wpływu na to, jak (państwa) są postrzegane przez publiczność za granicą" (s. 293). Ten typ polityki zagranicznej w Niemczech zaczęto uprawiać według autora w połowie lat dziewięćdziesiątych XX wieku. Postrzeganie państw jako przedsiębiorstw, konkurujących między sobą w środowisku międzynarodowym, spowodowało w Niemczech, że zintegrowane zostały działania tradycyjnej dyplomacji kulturalnej i promocji gospodarczej na rzecz „,przedsiębiorstwa Niemcy”. W tym procesie istotną rolę odegrał wywodzący się z FDP, liberalny minister spraw zagranicznych Klaus Kinkel, co wskazuje na wpływ preferencji jednostki na podejmowanie działań dyplomacji publicznej na rzecz państw. Jak podkreśla R. Hülsse, kultura dla K. Kinkela miała stać się jednym z narzędzi promujących niemieckie produkty eksportowe i przyciagających inwestycje. Idee te zostały wyłożone w exposé K. Kinkela z początku 1996 r. Dla R. Hülsse oznaczają one przełom w pojmowaniu niemieckiej zagranicznej polityki wizerunkowej, gdyż wtłaczają ją w ramy gospodarcze. W przygotowanej przez niemiecki rząd federalny cztery lata później „Konzeption 2000” pojawia się idea dialogu dla zapobiegania kryzysom międzynarodowym, a więc wykorzystanie miękkiej siły dla bezpieczeństwa państwa. Nowa zagraniczna polityka wizerunkowa jest uwarunkowana przez globalizację i ma przyczyny ekonomiczne, bo dla celów ekonomicznych jest $\mathrm{w}$ dużej części prowadzona. Ma jednak także przełożenie na politykę bezpieczeństwa Niemiec i zmienia kulturę bezpieczeństwa narodowego tego kraju ${ }^{16}$. To podejście kontynuował F. Steinmeier uznając, że państwa konkurują ze sobą m.in. przez swoje wizerunki na arenie międzynarodowej, tak jak konkurują przedsiębiorstwa ${ }^{17}$. R. Hülsse uznaje, że taka skomercjalizowana i ,spiarizowana" zagraniczna polityka wizerunkowa jest charakterystyczna przede wszystkim dla krajów wysoko rozwiniętych.

Obraz współczesnej dyplomacji publicznej byłby niepełny bez zwrócenia uwagi na nadawanie przekazów za granicę, za pomocą radia i telewizji i przy wykorzystaniu no-

\footnotetext{
14 Branding Post-Communist Nations. Marketizing National Identities in the New Europe, ed. N. Kaneva, Routledge, London 2011, s. 4.

15 R. Hülsse, The Catwalk Power: Germany's New Foreign Image Policy, ,Journal of International Relations and Development" 2009, vol. 12, s. 293-316.

${ }^{16}$ Zwrócił na ten proces uwagę K. Malinowski, w swojej książce, w której rozwija pojęcie kultury bezpieczeństwa narodowego P. Katzensteina. Patrz: K. Malinowski, Przemiany niemieckiej polityki bezpieczeństwa 1990-2005, Poznań 2009.

17 R. Hülsse, op. cit., s. 298.
} 
wych możliwości, jakie dają media online, w tym media społecznościowe. W tym obszarze prowadzi się zarówno badania w ujęciu instytucjonalnym, jak i analizę treści, aż po zaawansowane badania lingwistyczne. Większość współczesnych ujęć dyplomacji publicznej uznaje nadawanie programów telewizyjnych i radiowych za granicę za jedno z jej narzędzi. W związku z tym niezbędne jest wprowadzenie elementów badań nad mediami do stosunków międzynarodowych, w tym zwrócenie uwagi na znaczenie mediów jako niepaństwowych aktorów stosunków międzynarodowych. Niewiele uwagi poświęcono m.in. działalności transnarodowych firm medialnych o globalnym zasięgu. Uwzględnienie tych tematów, wprowadzenie metod analizy z medioznawstwa, ekonomii mediów, pozwoli na uniknięcie uproszczeń, jak wyolbrzymiania lub pomijania roli mediów w wydarzeniach międzynarodowych i polityce zagranicznej. W tym kontekście warto zwrócić uwagę na dyskusję o znaczeniu mediów społecznościowych i Al Jazeery w wydarzeniach w Afryce Północnej w 2011 r., która stała się okazją dla powrotu do rozważań nad relacjami między mediami a polityką zagraniczną. Kolejnych argumentów na rzecz włączenia analizy mediów do badań nad dyplomacją publiczną dostarczaja stacje radiowe i telewizyjne dla Białorusi oraz akcje opozycji w tym państwie jak „Rewolucja przez sieci społecznościowe”, wspierane m.in. przez telewizję Bielsat. Wskazują one przy tym, jak dawni odbiorcy zagranicznych przekazów radiowych, stosują nadawanie za granicę w nowej sytuacji międzynarodowej dla osiagnięcia zmiany społecznej. Dawni odbiorcy stali się nadawcami.

Działalność rozgłośni takich jak Voice of America, RFE, telewizji Al Hurra to kolejny przykład jednostronnej, informacyjnej dyplomacji publicznej. Dopiero wykorzystanie mediów społecznościowych, uzupełniających ofertę informacyjną oraz dających możliwość większego kontaktu z odbiorcami zmienia tę asymetrię. Oddziaływanie przez dyplomację kulturalną i media nadające za granicę od wielu lat analizowane jest z pozycji imperializmu kulturowego. Podejście geopolityczne, zwracające uwagę na nierówności w przepływie informacji nakłada się w tym przypadku na analizę skutków kulturowych. Zwolennicy tego podejścia uznają dyplomację publiczną za eufemizm. W analizie sytuacji krajów małych i średnich, które są przede wszystkim odbiorcami przekazów w komunikowaniu międzynarodowym, dodatkowo pojawia się problem języka, który zwykle nie pełni roli języka szerszej komunikacji. Sprzyja to peryferyjności tych państw. Dla badań nad przepływem informacji między państwami o nierównych potencjałach w komunikowaniu międzynarodowym zastosowano klasyczną teorię I. Wallersteina, dzieląc państwa na informacyjne centra, informacyjnych sąsiadów i peryferia informacyjne ${ }^{18}$. W ten sposób powstał łącznik między nauką o stosunkach międzynarodowych a badaniami nad mediami.

Wydaje się jednak, że klasyczny podział na centra i peryferie, ze względu na wzrost znaczenia narzędzi miękkiej siły jak dyplomacja publiczna w określaniu potęgi państwa, jest obecnie mniej efektywny niż zastosowanie analizy sieciowej. Pojęcie sieci jest pomocne w analizie wszystkich poziomów dyplomacji publicznej bowiem opisuje zarówno typ powiązań między dyplomatami (na poziomie pierwszym), jak i między in-

18 S. A. Gunaratne, Perspektywy i ograniczenia koncepcji systemu światowego $w$ analizie mediów: studium na przyktadzie Bliskiego Wschodu i Afryki Pótnocnej, „Zeszyty Prasoznawcze” 2001, nr 1-2, s. 42. 
nymi aktorami na pozostałych poziomach. Sieci społecznościowe pojawiają się obecnie na wszystkich trzech poziomach dyplomacji publicznej. Na poziomie pierwszym są one narzędziem MSZ w procesach komunikacji. Patrząc na dyplomację publiczną jako na sieć, można rządowi (MSZ) przypisać rolę węzła tej sieci (zwykle jeszcze MSZ nie pełnią takiej roli w mediach społecznościowych, mogą w nich jednak inicjować lub wspierać powstawanie wspólnot tematycznych, tzw. issue alliance ${ }^{19}$ ). W tym miejscu należy zaznaczyć, że dyplomacja publiczna może być badana przy zastosowaniu politologicznej analizy sieci, w której MSZ można przypisać rolę węzła sieci.

Powyższe rozważania weryfikuję na przykładzie państw post komunistycznych, które stały się członkami Unii Europejskiej w 2004 i 2007 r. Na podstawie tego przypadku można postawić hipotezę, że w regionie Europy Środkowej i Wschodniej kształtuje się dwustopniowy model dyplomacji publicznej. Ze względu na chronologicznie pierwsze zastosowanie kształtowania marki (zarówno do celów komercyjnych, jak i dla wspierania procesów przemian tożsamości kulturowej), składa się nań branding państwa w pierwszej fazie, który na skutek istotnych zdarzeń (jak akcesja do Unii Europejskiej) staje się jednym z narzędzi promocji państwa. W fazie drugiej wprowadza się dyplomację publiczna, która pełni rolę koordynująca, w tym dla współpracy między MSZ a organizacjami pozarządowymi. Badane państwa to kraje małe i średnie, które budują swoją pozycję międzynarodową przy ograniczonych zasobach środków twardych. W efekcie wykorzystują swój potencjał niematerialny, aby osiagnąć wiarygodność jako uczestnik stosunków międzynarodowych. Dążą do tego przez akcesję do lub zakładanie organizacji międzynarodowych, w tym regionalnych, dzięki czemu budują sieci współpracy. Ze względu na niewielkie znaczenie międzynarodowe stosują dyplomację niszową, wybierając specjalizacje w polityce zagranicznej. W ostatnich latach państwa te coraz wyraźniej specjalizują się w promocji demokracji w Europie Wschodniej, na Bałkanach Zachodnich, a na skutek ,,arabskiej wiosny” także w krajach arabskich. Ponieważ duża grupa ich obywateli mieszka za granica, mają możliwość prowadzenia dyplomacji publicznej poprzez diasporę (dyplomacja diaspory). Duże znaczenie dla państw post komunistycznych w Europie Środkowej i Wschodniej, a więc i Polski, ma dyplomacja historyczna, co wynika ze znaczenia przeszłości dla ich kultury politycznej, a w tym dla kultury polityki zagranicznej. Nie bez znaczenia jest ich położenie geopolityczne. Analizowanie tego przypadku wskazuje, jak konkretne wydarzenia (akcesja do UE, sprawowanie prezydencji Rady UE), przyspieszają powstawanie strategii komunikacyjnej rządów, w tym strategii dyplomacji publicznej oraz struktur (jak departamenty dyplomacji publicznej), odpowiedzialnych za realizację tych strategii. Wejście do Unii Europejskiej oznacza przy tym przejęcie metod dyplomacji publicznej krajów Europy Zachodniej. Wraz z rozwojem demokracji, do działalności tej włączane są organizacje pozarządowe. Dla krajów Europy Środkowej i Wschodniej, UE pozostaje ciagle (2011) jednym z głównych obszarów docelowych ich dyplomacji publicznej. Procesowi akcesji - z demokratyzacją i modernizacją - towarzyszy identyfikacja zasobów miękkiej siły i możliwości ich zastosowania za pomocą dyplomacji publicznej. Procesy te w dziesięciu badanych krajach, ze względu na

19 B. G. Smith, Socially Distributing Public Relations: Twitter, Haiti and Interactivity in Social Media, „Public Relations Review” 2010, vol. 36, s. 333. 
ich podobieństwo pod względem posiadanych zasobów twardych oraz w procesie uczenia się (mimetyzm) zastosowania zasobów miękkich, pozwala wysnuć hipotezę, że w regionie tym powstaje transformacyjny model nowej dyplomacji publicznej. Model ten obejmuje również polskie doświadczenia w tworzeniu dyplomacji publicznej. Z perspektywy 2011 r., mimo braku polskiej strategii dyplomacji publicznej w formie dokumentu rządowego, można wskazać na efektywne zastosowanie tego narzędzia do pozycjonowania Polski wewnątrz Unii Europejskiej. Na tym etapie badań nie jest jednak możliwe wyizolowanie dyplomacji publicznej jako samodzielnego czynnika sprawczego $\mathrm{w}$ tym procesie.

Dyplomacja publiczna, mimo że pojawia się w słownictwie reżimów niedemokratycznych, to narzędzie miękkiej siły, które współcześnie może w pełni rozwijać się w systemach demokratycznych, gdyż wymaga debaty w sferze publicznej, niezbędnej dla włączenia nowych aktorów i wypracowania strategii, a więc swobodnego procesu kształtowania opinii publicznej, a jednocześnie swobodnej debaty nad kształtowaniem przekazu za granicę. Modelowa sytuacja występuje wtedy, gdy zarówno nadawca, jak i odbiorca to państwo demokratyczne, o otwartym systemie nadawania i odbierania przekazów. Zarówno państwa demokratyczne jak i autorytarne stosują przy tym działalność propagandową (propagandę kierowaną za granicę). Jest ona niezbędnym elementem działan wojennych, uzupełniana o operacje psychologiczne.

Połączenie elementów nauki o stosunkach międzynarodowych i teorii komunikowania przynosi w przypadku badań nad dyplomacją publiczną pozytywne efekty. Wadą takiego interdyscyplinarnego podejścia, zwłaszcza w studiach przypadków, jest duża liczba zmiennych niezależnych, które bierze się pod uwagę badając modele dyplomacji publicznej. W studiach przypadków redukuje się więc tę liczbę poprzez wyizolowanie najbardziej istotnych zmiennych niezależnych. Ich dobór jest uwarunkowany podejściem badawczym autora. Na obecnym etapie rozwoju dyscypliny przeważają analizy prowadzone z perspektywy nauki o stosunkach międzynarodowych, w których jednak coraz częściej uwzględnia się dorobek innych dziedzin i dyscyplin.

\section{STRESZCZENIE}

Celem tekstu jest wskazanie na nową dyplomacją publiczną jako na obszar badawczy, który wymaga podejścia interdyscyplinarnego. Na obecnym etapie rozwoju tej dyscypliny dominują podejścia badawcze i narzędzia zaczerpnięte z nauki o stosunkach międzynarodowych. Autorka postuluje włączenie podstawowych paradygmatów badań nad komunikacją polityczną do analizy nowej dyplomacji publicznej. Na razie jednak nie można wskazać takiego podejścia badawczego, które wychodziłoby poza prostą sumę metod stosowanych w nauce o stosunkach międzynarodowych i badaniach nad komunikacją polityczną.

Na potrzeby artykułu dyplomacja publiczna została zdefiniowana jako symetryczna forma międzynarodowej komunikacji politycznej, której celem jest wspieranie osiagnięcia celów państwa za granicą poprzez wpływanie na opinię publiczną. Współcześnie dyplomację publiczną określa się jako „nową, aby odróżnić ją od dyplomacji publicznej Stanów Zjednoczonych, uprawianą przed 1999 r. oraz wskazać na dostosowanie tej formy komunikacji politycznej do procesów globalizacji, w tym do rosnącego znaczenia aktorów niepaństwowych w stosunkach międzynarodowych. W tym ujęciu dyplomacja publiczna nie jest tożsama z propagandą. 


\title{
NEW PUBLIC DIPLOMACY - FROM THE PERSPECTIVE OF INTERNATIONAL RELATIONS THEORY AND POLITICAL COMMUNICATION
}

\begin{abstract}
The paper has the objective to present public diplomacy as a discipline requiring interdisciplinary approach. At the current stage of development of the discipline, the approach rooted in the theory of international relations is dominating. The author suggests inclusion of the tools used for the analysis of political communication into the body of research on new public diplomacy. Therefore, there is nothing more as an aggregate of paradigms and tools of two disciplines implemented at the moment.

Public diplomacy was defined in the paper as a symmetrical form of international, political communication targeted at foreign public opinion in order to facilitate the achievement of the goals of state abroad. Currently, the adjective ,new” as added to public diplomacy, means that new public diplomacy is different from informational public diplomacy of United States before the liquidation of USIA. The new public diplomacy acknowledges non state organizations as actors of international relations and adjusts to the logic of globalization. New public diplomacy should not be equalized with political propaganda.
\end{abstract}


